\title{
NILAI KEARIFAN DALAM BABAD BANYUMAS
}

\author{
Kuntarto, Rindha Widyaningsih* \\ Fakultas Ilmu Budaya, Universitas Jenderal Soedirman, Indonesia \\ kuntarto_bobosan@yahoo.com, *reindha_84@yahoo.co.id \\ Muhamad Riza Chamadi \\ Fakultas Biologi, Universitas Jenderal Soedirman, Indonesia \\ riza.chamadi@gmail.com
}

DOI: 10.20884/1.jili.2019.10.2.2056

\begin{abstract}
Article History:
First Received:

ABSTRACT

$06 / 11 / 2019$

Babad Banyumas has an essential role as a medium of cultural preservation,

Final Revision: philosophical meaning, and value from the ancestors to the next generation. This study aims to find religious, social values in the Babad Banyumas.

$14 / 11 / 2019$

Available online: Babad Banyumas used as primary data is the Wirjaatmadja Banyumas chronicle version. The data was strengthened by literature studies and interviews with cultural figures from Banyumas, who were concerned about local wisdom studies. Analysis of values by using the reflection of the

$30 / 12 / 2019$ character, meaning of occurrence, and occasion in Babad Banyumas. Religious and social values obtained include the teachings of gratitude, religious values, the value of helping, the value of unity, the value of deliberation to reach consensus, the value of justice and general welfare, the value of peace and non-violence, and the value of family and harmony. The mandate consists of Babad Banyumas is not expressed explicitly in the text but is present implicitly through characters, advice, messages, stories, traditional advice, and events presented in the text. The reflection of wisdom values in the Babad Banyumas is an empirical measure to preserve local culture. The legacy of thought, as presented in the Babad Banyumas text, has important significance as a guide for behaving following the identity of the Banyumas community. The transfer of knowledge through the reflection of values in the Babad Banyumas plays an essential role in creating a national identity in order to strengthen national unity.
\end{abstract}

Keywords: Babad Banyumas; local wisdom; wisdom values; Wirjaatmadja

\section{PENDAHULUAN}

Akar intelektual masyarakat Jawa dapat dilacak melalui sistem pengetahuan yang tertuang dalam tradisi lisan dan tulis. Pewarisan ingatan kolektif atau pengetahuan masa lampau yang diturunkan antar generasi pada masyarakat yang telah mengenal tradisi tulis melahirkan karya sastra yang berhubungan dengan norma, adat, gejala sosial dan menjadi cermin atau deskripsi kehidupan (mimetik) masyarakat di jaman itu (Khoeriyah, 2017). Tradisi tulis yang memuat sejarah dan mengandung karya sastra misalnya yang terdapat dalam babad, suluk, lontarak, hikayat, tembang, dan lain sebagainya (Satibi, 2015). 
Babad merupakan sebuah titik temu dari karya sasatra dan realitas sejarah. Babad tidak hanya dianggap sebagai sebuah dokumen sejarah, namun telah berpadu dengan unsur kreativitas penulis dengan memberikan nilai dan makna lewat cerita. Penulis babad lebih menekankan pada pemberian makna dan eksistensi manusia lewat cerita yang boleh jadi tidak benar secara faktual namun masuk akal secara maknawi (Satibi, 2015; Teeuw, 1984). Babad menghadirkan cerita antara history dan story namun sekaligus mampu memberikan pembelajaran mengenai nilai-nilai asli yang dianut oleh masyarakat dimana babad tersebut lahir (Widianti, Nuryatin, \& Indiatmoko, 2017). Babad memiliki fungsi sebagai legitimasi atas silsilah atau sebuah kejadian/peristiwa sekaligus menggambarkan mengenai filosofi dan pemikiran serta kebudayaan dimana teks tersebut berasal.

Studi terhadap Babad Banyumas menunjukan setidaknya ditemukan adanya 101 teks yang terdiri dari teks naskah sebanyak 43 (empat puluh tiga), teks ketikan sebanyak 38 (tiga puluh delapan), dan teks cetakan sebanyak 20 (dua puluh) (Priyadi, 2006). Hal ini menunjukan bahwa masyarakat Banyumas memiliki kedinamisan yang tinggi dalam proses penciptaan kembali teksteks sejarah. Kekayaan versi babad yang dimiliki oleh Babad Banyumas juga memiliki makna penting sebagai pengetahuan lokal yang digunakan oleh masyarakat lokal untuk bertahan hidup dalam suatu lingkungannya yang menyatu dengan sistem kepercayaan, norma, budaya (Khoeriyah, 2017). Kekayaan teks yang dimiliki oleh Banyumas memiliki arti penting bagi keberlanjutan dan kelestarian kebudayaan di tengah arus modernitas yang banyak menggeser nilai budaya lokal. Melalui babad generasi-generasi mendatang diwarisi nilai-nilai pemikiran dan filosofi yang telah mengakar semenjak zaman leluhur. Arti penting nilai-nilai ini adalah untuk mengarahkan tingkah laku individual dalam situasi sehari-hari dan juga untuk mengekspresikan kebutuhan dasar yang berupa motivasional (Kusumah, 2013).

Diantara sekian banyak versi Babad Banyumas, teks yang paling menarik dan populer adalah Babad Banyumas versi Wirjaatmadja. Versi Wirjaatmadja merupakan teks Babad Banyumas merupakan teks babad yang bersifat terbuka karena mengalami proses penyalinan secara terus menerus (Priyadi, 2019). Babad Banyumas versi Wirjaatmadja sejauh ini merupakan teks yang paling komprehensif sehingga digunakan sebagai teks sejarah Banyumas yang dipergunakan oleh Pemerintah Daerah Kabupaten Banyumas.

Warisan pemikiran sebagaimana yang disajikan dalam teks Babad Banyumas memiliki arti penting sebagai pedoman dalam berprilaku yang sesuai dengan identitas dan jatidiri masyarakat Banyumas serta sebagai upaya melestarikan kebudayaan lokal. Menilik dari arti penting nilainilai luhur kearifan lokal Banyumas maka penelitian ini bertujuan untuk menemukan refleksi 
nilai-nilai kearifan yang terkandung dalam Babad Banyumas. Secara spesifik penelitian ini bertujuan untuk memberikan pembelajaran mengenai nilai baik dan arif yang dapat dijadikan sebagai pedoman nilai bagi generasi mendatang sebagai penguat identitas.

\section{METODE}

Data primer yang digunakan dalam penelitian ini adalah Babad Banyumas versi R. Aria Wirjaatmadja yang secara praksis berfungsi sebagai teks sejarah Banyumas yang digunakan secara resmi oleh Pemerintah Daerah Kabupaten Banyumas. Data skunder diperoleh melalui wawancara secara mendalam kepada tokoh dan budayawan yang memiliki fokus kajian tentang kearifan lokal Banyumas. Selain itu data juga diperkuat dengan studi literatur terhadap buku dan jurnal yang relevan dengan tema.

Pendekatan analisis digunakan untuk mengetahui makna yang dikandung dalam cerita dan sejarah, sifat dan karakter tokoh serta warisan pemikiran yang tertuang dalam Babad Banyumas. Penelitian ini difokuskan pada penelitian terhadap identifikasi dan inventarisasi nilai. Dalam tingkatan ini penelitian dilakukan dengan cara melakukan refleksi dan analisis nilai yang diperoleh melalui Babad Banyumas melalui watak dan karakter tokoh-tokoh yang diceritakan dalam babad, makna peristiwa dan kejadian yang menjadi sejarah, dan nasihat atau warisan pemikiran yang disampaikan dalam babad. Setelah menemukan nilai-nilai tersebut (proses identifikasi) maka dilakukan inventarisasi nilai-nilai yang terdapat dalam Babad Banyumas secara sistematis.

\section{HASIL DAN PEMBAHASAN}

\section{Nilai Kearifan dalam Babad Banyumas}

Babad Banyumas mengandung nilai-nilai kearifan yang sarat akan makna filosofis. Nilai yang terkandung dalam Babad Banyumas juga sekaligus menunjukan karakter dan nilai acuan umum dalam kehidupan bermasyarakat dan menjadi penanda jatidiri khas masyarakat Banyumas. Karakter asli orang Banyumas adalah cablaka atau terbiasa berbicara apa adanya. Dalam relasi sosial yang ditampilkan, orang Banyumas lebih bersifat egaliter dengan meniadakan status sosial dalam berinteraksi (Widyaningsih, 2014). Karakter khas orang Banyumas ini salah satunya didasari oleh ajaran kearifan lokal masyarakat Banyumas. Berdasarkan hasil analisis yang dilakukan dalam teks Babad Banyumas diperoleh nilai-nilai sebagai berikut: 


\section{Ajaran Berterima Kasih}

Ajaran berterima kasih selalu ditemukan dalam Babad Banyumas, khususnya pantangan yang menyatakan bahwa orang Banyumas tidak boleh menganiaya, membunuh atau memakan daging ayam hutan. Pantangan ini muncul sebagai wujud rasa terima kasih Raden Baribin atas pertolongan ayam hutan yang telah menyelamatkan nyawanya (Wirjaatmadja, 1898).

Dalam Babad Banyumas dikisahkan bahwa Raden Baribin diramalkan oleh Ki Ajar Wanatara akan menjadi raja Majapahit menggantikan kakaknya dengan syarat Raden Baribin tidak boleh meninggalkan ibu kota. Ramalan ini rupanya meresahkan hari raja yang sedang berkuasa sehingga Baribin kemudian diusir keluar dari wilayah Majapahit. Raja rupanya tidak menghendaki Baribin selamat sehingga mengumumkan larangan membantu Baribin selama dalam perjalanan kepada seluruh warga, dan apabila ada yang melanggar maka akan dikenai hukuman yang berat. Kepergian Baribin ternyata membawa serta anak angkatnya yang masih anak raja sehingga raja menjadi semakin marah dan menyuruh Patih Bantheng untuk mengambil kembali puteri raja yang dibawa serta oleh Baribin. Dalam perjalanannya Baribin merasa kelelahan dan makan mentimun wulan, akibatnya dia hampir saja tertangkap pasukan Patih Bantheng yang mengejarnya. Baribin kemudian bersembunyi di dekat ayam hutan untuk menghindari pasukan Majapahit. Ayam hutan adalah binatang yang dikenal oleh masyarakat sebagai bianatang yang inderanya sangat peka, apabila ada manusia di dekatnya maka ayam hutan akan pergi dan meninggalkan tempat itu. Namun ketika Baribin bersembunyi di dekat ayam hutan bertengger, ayam tersebut tenang dan tidak menunjukkan reaksi apapun, sehingga pasukan Majapahit mengira tidak mungkin ada orang di sekitar tempat itu. Dengan demikian maka selamatlah Baribin dari pengejaran pasukan Mataram berkat ayam hutan tersebut.

Hal inilah yang kemudian memunculkan pantangan di dalam masyarakat Banyumas, bahwa mereka tidak boleh memakan mentimun wulan (mentimun putih), karena gara-gara memakan mentimun wulan Baribin hampir saja tertangkap pasukan Mataram. Selain itu muncul pula pantangan untuk tidak boleh memburu, menyakiti atau mengkonsumsi daging ayam hutan sebagai wujud terima kasih karena berkat ayam hutan maka Baribin selamat dari pengejaran pasukan Mataram (Adisarwono, 1985).

\section{Nilai Religius}

Babad Banyumas mengajarkan beberapa ajaran moralitas terkait dengan nilai religius dan pandangan keagamaan. Salah satunya adalah adanya kepercayaan kepada Hyang Widhi, bahwa untuk mendapatkan wangsit sesuai dengan kehendak Hyang Widhi maka harus dijalani dengan 
tapa pendem selama empat puluh hari (Wirjaatmadja, 1898). Hal ini menunjukan bahwa faktor religiusitas adalah bagian dari fitrahyang melekat dalam diri manusia.

Dalam tataran tradisi, perwujudan nilai religius ditemukan dalam upacara religi, khususnya upacara tahunan Sadranan. Diceritakan dalam Babad Banyumas bahwa masyarakat Banyumas telah mengenal tradisi sadranan dengan melakukan berbagai ritual. Rangkaian upacara sadranan dimulai pada hari pertama dengan melakukan upacara yang dipimpin oleh Pendeta Stapaka dan Mpu dari Paruh. Pemujaan Buddha dilakukan dengan cara seluruh pendeta mengelilingi Sang Raja yang duduk di Balai Witana. Selanjutnya, disusul dengan doa untuk memanggil arwah Rajapatni dan Buddhaloka yang masuk dalam puspasarira (patung bunga). Pada malam harinya, pemujaan dilakukan dengan cara semedi dan melantunkan puji-pujian. Keesokan paginya, puspasarira yang telah berisi arwah Rajapatni dikeluarkan ke Manguntur dan didudukan di singgasana. Pemujaan dilakukan lagi dengan urutan semua pendeta, raja, permaisuri, dan seluruh keluarganya, pejabat daerah dan raja seberang sebagai tamu kehormatan (Wirjaatmadja, 1898).

Setelah pemujaan maka dilakukan acara persembahan dan sajian dari berbagai raja dan pemimpin daerah yang berada di bawah kekuasaan Majapahit. Acara persembahan ditutup pada malam ketujuh dengan melakukan taburan uang, pembagian pakaian, dan pakaian kepada seluruh kasta yang ada. Perayaan selama tujuh hari tujuh malam tersebut dimeriahkan dengan berbagai hiburan dan pertunjukan kesenian. Pada hari kedelapan, para pendeta Buddha melakukan penghormatan bersama-sama dengan menyanyikan lagu pujian yang dipersembahkan secara khusus untuk arwah Rajapatni yang berada di Buddhaloka. Kemudian puspasarira diturunkan dari singgasana yang disusul dengan perbaikan makam Rajapatni.

Tradisi sadranan hingga kini masih dilestarikan dan menjadi ritual rutin tahunan yang dilaksanakan di kompleks makam Dawuhan yang dikenal dengan nama Astana Redi Bandungan yang merupakan tempat pemakaman raja-raja dan bupati Banyumas keturunan Raden Baribin. Upacara ini awalnya dilakukan karena adanya budaya konformisme terhadap raja-raja Majapahit yang merupakan patron dari Banyumas.

Tradisi sadranan pada dasarnya merupakan ungkapan refleksi sosial-keagamaan (Kastolani \& Yusof, 2016). Masyarakat Banyumas dan juga Jawa pada umumnya merupakan masyarakat yang religius bahkan jauh telah ada sebelum masuknya agama-agama. Orang Jawa meyakini bahwa selain yang ada dalam dunia nyata juga ada hal-hal gaib yang tidak kasat mata (Suwarno, Saddhono, \& Wardani, 2018). Salah satu wujud religiusitasnya adalah adanya penghormatan kepada arwah leluhur dan menganggap adanya suatu zat yang lebih tinggi dan mulia daripada manusia (Nasucha, 2000). Persembahan kepada arwah leluhur juga mencerminkan adanya rasa menghormati kepada hal yang sifatnya gaib. Masyarakat Banyumas 
pada dasarnya merupakan masyarakat yang religius, mengakui adanya peran tuhan dalam proses kehidupan. Kepercayaan terhadap arwah leluhur merupakan suatu bentuk religiusitas dan mengandung nilai dasar ketuhanan di dalamnya. Upacara sadranan merupakan pengejawantahan atas jiwa religius yang mengakui bahwa kekuatan manusia bukanlah yang tertinggi di alam semesta ini.

\section{Nilai Tolong Menolong}

Masyarakat Banyumas merupakan masyarakat yang komunal dan memiliki keterikatan primordial yang kuat. Kultur demikian menyebabkan rasa kekeluargaan tumbuh secara alamiah dalam lingkungan masyarakat. Rasa kebersamaan sebagai keluarga inilah yang menumbuhkan kebiasaan tolong menolong (Putra, Bahtiar, \& Upe, 2018). Nilai tolong menolong yang dapat ditemukan dalam Babad Banyumas yaitu pemberian sedekah kepada masyarakat yang hidupnya berkekurangan pada saat sadranan.

Rasa tolong menolong dalam upacara sadranan sesungguhnya mulai tampak dari persiapan upacara itu sendiri. Ritual upacara yang panjang tentulah memerlukan sokongan dana, tenaga dan juga pemikiran yang tidak sedikit. Para donatur dan relawan bekerja sama tanpa pamrih untuk mewujudkan acara sadranan agar sukses dan berjalan lancar. Bagi yang tidak mampu memberikan sumbangan berupa uang dan harta maka bantuan yang diberikan berupa sumbangan tenaga yang juga sangat berperan penting dalam kesuksesan acara sadranan.

Upacara sadranan memiliki fungsi sosial dan merupakan simbol bahwa rasa kepedulian dan perhatian kepada sesama yang masih membutuhkan pertolongan merupakan sesuatu yang dibiasakan dan menjadi sesuatu yang nyata ditemui dalam kehidupan sehari-hari (Nasucha, 2000). Pada akhirnya tradisi sadranan ini mengalami perluasan makna karena dikaitkan dengan sedekah dan beramal (Kastolani \& Yusof, 2016). Rasa tolong menolong yang dimulai semenjak persiapan upacara sadranan, pelaksanaan upacara hingga pemberian bantuan kepada masyarakat yang berkekurangan pada puncak acara sesungguhnya merupakan simbol bahwa sifat tolong menolong dan juga gotong royong merupakan hal yang memang ada dan dipegang teguh oleh masyarakat sejak dulu hingga kini dan masa yang akan datang.

\section{Nilai Persatuan}

Diceritakan dalam Babad Banyumas bahwa Raden Baribin memilih untuk meninggalkan Majapahit dan melakoni tapa prihatin. Hal ini dimaksudkan untuk meningkatkan kualitas diri dengan berlatih mengekang hawa nafsu duniawi untuk mencapai keberhasilan. Dalam hal ini 
Raden Baribin menerapkan perilaku asketis, yaitu memupuk kekuatan batin agar dapat menguasai nafsu diri (jagad cilik) agar mampu menjadi pemimpin yang menguasai dunia yang lebih luas (jagad gedhe. Kisah Raden Baribin ini menjadi sesuatu yang sangat mempengaruhi mentalitas dan juga cara pandang masyarakat Banyumas yang beranggapan kesuksesan akan lebih mudah diraih apabila melakukan hijrah mencari penghidupan di luar wilayah Banyumas (Herusatoto, 2008).

Banyaknya masyarakat yang melakukan hijrah lambat laun akan dapat mempengaruhi tingkat kekerabatan dalam masyarakat, oleh sebab itu diperlukan suatu ajang silaturahmi yang bertujuan untuk merekatkan hubungan primordial dan kekeluargaan serta persatuan masyarakat Banyumas. Silaturahmi memegang peranan penting dalam rangka menjaga perasaan saling memiliki dan menjadi bagian bersama (belongingness) yang merupakan cikal bakal dari rasa persatuan.

Kegiatan sadranan yang dilakukan di kompleks makan Dawuhan yang terdiri dari rangkaian acara dan ritual tiap tahun mengandung fungsi sosial. Tradisi sadranan mampu "memanggil" mereka yang memiliki keterikatan batin dengan daerahanya. Tradisi ini memiliki peran yang kuat dalam menjaga silaturahmi dan kebersamaan orang-orang yang mengaku dirinya adalah orang Banyumas dan mengingatkan darimana mereka berasal. Tradisi sadranan di makam Dawuhan tetap dilestarikan hingga saat ini salah satu alasan kuatnya adalah sebagai ajang silaturahmi orang Banyumas dan dari luar Banyumas agar rasa kekeluargaan dan juga persatuan dapat terjaga (Adisarwono, 1985).

\section{Musyawarah Untuk Mufakat}

Teks Babad Banyumas memuat tokoh yang bernama Raden Kaduhu. Raden Kaduhu adalah keturunan Raja Majapahit dan Pajajaran yang menjadi adipati di Wirasaba. Kaduhu memiliki keistimewaan yaitu tidak akan terbakar meskipun masuk dalam perapian, bahkan wajahnya menjadi bersinar seperti Dewa Surya. Keistimewaan ini menyebabkan Kaduhu diadopsi oleh Adipati Wirasaba, Surawin, karena sang adipati tidak memiliki anak. Kelak Kaduhu lah yang mewarisi tahta sang ayah angkat sebagai adipati Wirasaba(Adisarwono, 1985).

Dikisahkan Kaduhu pergi mewakili ayah angkatnya ke Majapahit untuk menyerahkan upeti pada bulan Phalguna (Februari-Maret). Wirasaba merupakan salah satu negeri yang berada di bawah kekuasaan Majapahit yang mempunyai kewajiban hadir di ibu kota kerajaan. Selanjutnya, pada bulan Caitra (Maret-April), kepala daerah, para menteri, perwira, kepala desa, dan pendeta dari tiga aliran agama mengadakan musyawarah besar setiap tahun di ibu kota.

Tradisi musyawarah dari Majapahit ini kemudian diteruskan juga di Banyumas. Dalam 
Babad Banyumas dijelaskan bahwa pada masa pemerintahan Wargautama I, Kabupaten Wirasaba yang berada di bawah kekuasaan Kanjeng Sultan Hadiwijaya (Jaka Tingkir) setahun sekali wajib menghadiri musyawarah besar kerajaan yang disebut dengan Pasewakan Ageng, dalam acara tersebut daerah yang berada di bawah kekuasaan Pajang wajib menyerahkan upeti kepada sultan berupa hasil bumi yang berupa bahan mentah maupun yang sudah matang (jadi), hasil kerajinan yang indah-indah, baik, dan terpilih yang dalam bahasa Jawa disebut dengan glondong pengareng-areng, peni-peni raja peni guru bakal guru dadi, sebagai tanda penghormatan dan tanda masih menjunjung pemerintahan Pajang(Wirjaatmadja, 1898).

Dari kisah ini dapat disimpulkan bahwa budaya musyawarah dalam mengambil keputusan sudah ada sejak zaman dahulu kala. Walaupun raja Majapahit memiliki kekuasaan yang sangat besar dan dapat memerintah sesuka hatinya serta memiliki daerah bawahan yang sangat luas, namun tidak lantas menjadikan sang raja arogan dan mengambil keputusan secara sepihak. Pendapat dan juga masukan dari berbagai elemen kerajaan didengar dan ditampung secara khusus dan serius bahkan menjadi agenda tahunan yang berlangsung dalam kurun waktu yang cukup panjang, yaitu sekitar dua bulan lamanya.

Pengambilan keputusan secara musyawarah tidak hanya berlaku untuk penanganan permasalahan di tingkat terendah, yaitu desa, namun juga hingga tingkat tertinggi di wilayah kerajaan. Musyawarah dilakukan untuk mencapai mufakat dan kesepakatan bersama yang didahului dengan mendengarkan laporan dan juga usulan serta pertimbangan dari banyak pihak. Dengan demikian diharapkan dapat dihasilkan keputusan dan kebijakan yang mampu mengatasi berbagai persoalan dengan cara yang arif dan bijaksana. Musyawarah secara nyata merupakan cara yang efektif dalam penanganan permasalahan bagi daerah yang cakupannya luas dan difersivitas masyarakatnya sangat tinggi. Hal ini dibuktikan bahwa semenjak zaman Majapahit pun musyawarah sudah dilakukan, bahkan menjadi agenda tahunan yang wajib untuk dihadiri oleh seluruh daerah di bawah kekuasaan Majapahit.

Prinsip musyawarah telah diwariskan oleh para leluhur dan menjadi suatu agenda penting yang digarap secara serius, hal tersebut terbukti dari waktu pelaksanaan musyawarah yang tidak sebentar dengan persiapan yang sebaik-baiknya dan merupakan kegiatan rutin yang diadakan setiap tahun. seorang raja atau sultan tidak dapat mengetahui secara pasti kegiatan dan peristiwa yang terjadi di masing-masing daerah bawahannya karena luasnya daerah kekuasaannya tersebut. Oleh sebab itu peran Demang dan Adipati/pemimpin daerah menjadi penting untuk diikutsertakan dalam penyusunan strategi pemerintahan dan pengambilan keputusan karena mereka lah yang lebih tahu dengan pasti kondisi masing-masing daerahnya. Keputusan dan 
kebijakan yang diambil berdasarkan fakta dan data lapangan serta memperoleh persetujuan bersama sangat penting dalam menjaga stabilitas negara sehingga tidak timbul pemberontakan dan rakyat menjadi sejahtera. Musyawarah menjadi salah satu tradisi warisan leluhur yang masih sangat sesuai dengan kondisi negara Indonesia saat ini dan menjadi salah satu ciri khas bangsa Indonesia.

\section{Nilai Keadilan dan Kesejahteraan Umum}

Diceritakan dalam Babad Banyumas bahwa kegiatan musyawarah atau pasewakan ageng pada bulan Caitra seringkali menganggkat tema penting hubungan antara raja dan rakyat yang seringkali dilambangkan dengan ayam hutan dan singa. Dikisahkan sebelumnya banyak penduduk yang meninggalkan desanya untuk menghindari pungutan pajak dan kerja wajib yang membebani rakyat, rakyat menjadi tertekan dan akhirnya memberontak kepada penguasa.

Hasil keputusan musyawarah adalah pajak yang masuk ke kerajaan dimanfaatkan untuk membangun dan memelihara kesejahteraan umum. Hal ini juga mengakibatkan adanya pengawasan yang ekstra ketat terhadap para petugas pajak. Raja juga menekankan kepada mereka untuk meningkatkan ketaatan pada ajaran agama yang dipeluknya agar tidak melakukan penyimpangan dalam menjalankan tugas.

Raja Majapahit dalam hal ini menerapkan apa yang disebut sebagai keadilan bagi rakyatnya sehingga dapat tercapai kesejahteraan umum. Hal ini kemudian ditiru oleh penguasapenguasa di Banyumas yang merupakan daerah kekuasaan Majapahit. Penguasa menginginkan hubungan yang baik antara rakyat dan penguasa, dan penguasa memiliki komitmen untuk mensejahterakan penduduknya sehingga tidak terulang kejadian banyak penduduk yang memberontak atau meninggalkan desanya. Keadilan dan kesejahteraan umum menjadi tema penting yang menjadi perhatian pemerintah oleh sebab itu pengaturannya diabuat sedemikian rupa agar rakyat tidak protes dan melakukan pemberontakan.

\section{Nilai Cinta Damai dan Anti Kekerasan}

Dikisahkan dalam Babad Banyumas bahwa pendiri dinasti Banyumas dan pembangunan ibu kota baru adalah Jaka Kaiman yang memiliki nama kecil atau garbhopatti Bagus Mangun atau Jaka Semangun yang merupakan cucu dari Raden Baribin. Nama Bagus Mangun sendiri berarti menunjukkan sifat Mangunah, artinya beliau dapat menjadi seorang adipati karena keimanan yang dimilikinya, oleh sebab itu beliau juga disebut dengan Jaka Kaiman (Priyadi, 2019), yang kemudian menikah puteri Adipati Wargautama I, yaitu Nyai Mas Rara Sugatiman.

Setelah menikah, Bagus Mangun mendapatkan keris Gajah Endra dari ayah angkatnya, 
yaitu Kiai Tolih dengan pesan bahwa keris tersebut tidak boleh dibawa ke medan perang selama tujuh turunan. Hal ini dimaksudkan agar Bagus Mangun tidak perlu memerangi orang-orang Toyareka sebagai pelampiasan dendam atas kematian mertuanya.

Perpindahan Bagus Mangun dan pantangan keris Gajah Endra merupakan pesan yang penuh dengan cinta damai dan anti kekerasan meskipun pihak Wirasaba sangat dirugikan dengan fitnah pihak Toyareka terhadap Adipati Wargautama I. Hakikatnya Bagus Mangun dengan penuh keimanan dan pengendalian diri berusaha untuk membunuh dendam dan menggalang cinta damai, dan hal inilah yang mengantarkannya kepada kejayaan.

Babad Banyumas memberikan pembelajaran bahwa kejahatan tidak selamanya harus dibalas dengan kejahatan dan memberikan pesan bahwa perdamaian merupakan hal yang baik dan konstruktif. Selain itu nilai lain yang coba ingin disampaikan adalah pentingnya pengendalian diri. Pembelajaran paling penting dari terbunuhnya Adipati Wargautama I adalah disebabkan karena kurangnya pengendalian diri dan kurang hati-hati dalam memproses informasi. Catatan kelam ini kelak kemudian hari dijadikan sebagai suatu pelajaran berharga bahwa segala tindakan yang dilakukan dengan tanpa pertimbangan yang matang pada akhirnya akan membawa kerugian.

\section{Nilai Kekeluargaan dan Kerukunan}

Adipati Wargautama I merupakan tokoh penting yang bahkan setelah kematiannya masih memberikan pembelajaran kepada generasi penerus melalui symbol. Dikisahkan dalam sejarah Banyumas bahwa setelah kematian Adipati Wargautama I beliau dimakamkan di di Dukuh Pekiringan, Desa Klampok, Banjarnegara di sebelah selatan Sungai Serayu. Pemakaman tersebut terdiri dari makam Adipati Wargautama I, istri, dan jimat-jimat andalannya, dan bersebelahan dengan makam beliau adalah makam sahabatnya Raden Ngabehi Winoto yang merupakan keturunan Tionghoa (Adisarwono, 1985). Semasa hidup Raden Ngabehi Winoto memiliki peran yang penting dalam membantu Adipati Wargautama I menjalankan pemerintahan.

Adipati Wargautama I mewariskan suatu pemikiran dan nilai penting bagi generasi penerusnya. Nilai persahabatan dan kekeluargaan tidaklah selalu harus memiliki suku, agama maupun pandangan yang sama. Perbedaan adalah hal yang niscaya, dan saling menghargai sesama walaupun berbeda sehingga dapat memajukan kehidupan masyarakat bersama, dan hal ini disimbolkan dengan penempatan makam sahabat sang adipati yang merupakan keturunan Tionghoa bersebelahan dengan makam Adipati Wargautama I. 


\section{Pembahasan}

Babad Banyumas dihadirkan dalam bentuk narasi yang memberikan pembelajaran penting sepanjang masa melalui nilai-nilai moral dan kearifan yang terkandung di dalamnya. Babad Banyumas mengandung nilai kearifan lokal yang mampu menunjukan identitas kepribadian bangsa (Maulidina, Wardani, \& Suryanto, 2017). Amanat yang terkandung di dalam babad tidak tersajikan secara ekspisit dalam teks, namun hadir secara implisit melalui tokoh, perwatakan, nasehat,, pesan, cerita, anjuran tradisi, maupun peristiwa yang disajikan dalam teks (Rockhyatmo, 2018). Babad Banyumas mengajarkan nilai kearifan yang berguna bagi tindak kebijaksanaan dan kecerdikan akal budi.

Dalam tradisi masyarakat Banyumas pentingnya berterima kasih bahkan berusaha dilanggengkan melalui pantangan. Pantangan bagi masyarakat Banyumas untuk tidak mengkonsumsi ayam hutan merupakan nasihat agar keturunan Raden Baribin kelak tidak melupakan jasa dan pertolongan orang lain, bahkan termasuk binatang. Budaya terima kasih mengajarkan kita untuk menghargai jasa orang lain dan juga menghormati, baik kepada sesama manusia, alam sekitar maupun dengan Tuhan. Untuk mencapai perkembangan pribadinya yang wajar manusia tidak mungkin mampu mencukupi kebutuhannya sendiri dan mutlak memerlukan bantuan dari pihak lain.

Rasa terimakasih secara vertikal juga ditampilkan dalam narasi teks Babad Banyumas. Ungkapan terimakasih ini misalnya ditampilkan dalam tradisi sadranan. Tradisi sadranan sendiri tidak hanya mengandung nilai tunggal, namun banyak aspek nilai yang digali dari tradisi sadranan. Upacara ini dikenal oleh hampir seluruh masyarakat Jawa, demikian pula masyarakat Banyumas. Sadranan sesungguhnya berasal dari budaya Majapahit. Jika ditelusuri ke belakang, pendiri Banyumas yaitu Raden Baribin, merupakan orang Majapahit, maka tidak heran apabila kebudayaan, adat istiadat dan kebiasaan di Banyumas terpengaruh oleh budaya Majapahit (Adisarwono, 1985).

Sadranan secara panjang lebar diceritakan oleh Mpu Prapanca dalam karyanya yang berjudul Kakawin Negarakertagama, terutama pada pupuh 63 hingga 67. Upacara Sraddha oleh lidah orang Jawa secara berangsur-angsur dibaca sadran atau sadranan. Upacara sadranan dilaksanakan ada bulan kedua, yaitu bulan Bhadra atau Bhadrapada (Agustus-September) tahun 1284 Saka atau 1362 Masehi. Upacara tersebut diselenggarakan oleh Hayam Wuruk atas perintah Rani Tribhuanawijayotunggadewi dalam rangka memperingari 12 tahun wafatnya Sri Rajapatni (nenek Hayam Wuruk) (Priyadi, 2013). 
Sadranan merupakan sebuah perwujudan religiusitas masyarakat yang menunjukan kesadaran bahwa ada zat yang lebih tinggi dibandingkan manusia. Sadranan dalam perkembangan selanjutnya merupakan budaya konformisme terhadap keturunan Raden Baribin yang berasal dari Majapahit dan merembes pada keturunan Bana Keling (Adisarwono, 1985). Dalam tradisi yang lebih kontemporer, upacara sadranan lebih kepada penerusan adat kebiasaan dan penghormatan kepada leluhur dan pemimpin Banyumas yang telah berjasa mengembangkan daerah Banyumas.

Nilai tolong-menolong adalah nilai kearifan lain yang dapat dihayati dari sadranan. dinarasikan dalam teks Babad Banyumas, Gadjah Mada sebagai Patih Amangkubumi memberikan himbauan kepada seluruh pejabat untuk berpartisipasi dan memberikan sumbangan dalam rangka menyelenggarakan upacara sadranan yang tentunya menghabiskan banyak dana karena dilakukan selama delapan hari. Upacara ini dipusatkan di Balai Manguntur, yaitu bangsal penghadapan agung yang dihias dengan megah yang terletak di Setinggil.

Prinsip suka menolong dan bekerjasama dengan orang lain sesungguhnya merupakan perwujudan nilai praksis dari nilai dasar kemanusiaan. Nilai ini kemudian diperkuat dengan penerapan nilai instrumental melalui peraturan kerajaan atau daerah untuk pelaksanaan sadranan yang rutin dilakukan setiap tahunnya. Kehidupan masyarakat yang terikat secara primordial dan memiliki rasa kekeluargaan yang tinggi menyebabkan tolong menolong masih tetap lestari hingga sekarang. Sifat ini merupakan salah satu karakter unggul dari masyarakat Jawa pada khususnya dan bangsa Indonesia pada umumnya (Yunus, Ks, Mintosih, Soeloso, \& Soimun, 1995). Kehidupan masyarakat yang didominasi oleh kultur agraris dan memiliki ketergantungan dengan alam yang cukup tinggi menyebabkan banyak hal yang tidak mungkin dilakukan secara perseorangan, maka kekeluargaan dan gotong royong menjadi jawaban atas persoalan kehidupan. Karakter suka tolong menolong berperan penting dalam membentuk mentalitas bangsa yang dapat mempererat persatuan (Putra et al., 2018).

Nilai keadilan dan kesejahteraan umum adalah aspek nilai lain yang dapat ditemui dalam teks Babad Banyumas. Bahwa seorang pemimpin bertanggungjawab terhadap rakyatnya dengan menghadirkan kesejahteraan dan mampu menjadi pemimpin yang adil. Dalam konteks yang lebih modern, pada buku Sejarah Banyumas dijelaskan salah satu upaya pemerintah dalam rangka mencapai kesejahteraan adalah dengan cara membangun fasilitas-fasilitas umum seperti alat perhubungan atau kendaraan/transportasi, dibangunnya jembatan Sungai Serayu pada tahun 1891, pembangunan jalan kereta api pada tahun 1886, pembangunan kantor Bank Kabupaten (Apdeling) pada tahun 1896, pembangunan lumbung desa pada tahun 1895, saluran irigasi pada 
tahun 1884 yang mata airnya berasal dari Sungai Serayu, pembangunan rumah sakit pada tahun 1925 dengan nama Rumah Sakit Juliana, dan aneka organisasi lembaga pendidikan mulai dari sekolah desa hingga sekolah tinggi dan sekolah guru serta pembangunan instalasi listrik dan air minum dikenal mulai tahun 1928 dan 1929. Selain itu juga dikenal adanya usaha peternakan dan juga usaha untuk menjaga kesehatan dan sanitasi lingkungan melalui upaya pemberantasan penyakit malaria (Adisarwono, 1985).

Terbunuhnya Adipati Wargautama I memberikan pembelajaran yang sangat berharga, bahwa pengendalian diri yang kurang dapat merugikan dan tidak selamanya kejahatan harus dibalas dengan kejahatan. Cinta damai akan menghadirkan tata kehidupan yang lebih mensejahterakan karena prinsip harmoni pada dasarnya adaldah syarat bagi terwujudnya kehidupan yang adil dan sejahtera.

Kematian Adipati Wargautama I sendiri memberikan banyak makna dan pembelajaran, bahkan hingga setelah pemakamannya pun masih menyimbolkan makna dan memberikan pesan implicit yang mendalam. Sudah menjadi kebiasaan kompleks pemakaman raja/penggede adalah terdiri dari pemakaman istri, anak, maupun keluarganya, namun kompleks pemakaman Adipati Wargautama I memiliki keistimewaan yaitu bersebelahan dengannya adalah makam sahabatnya yang merupakan keturunan Tionghoa. Hal ini sedikit berbeda dengan kebanyakan kompleks makam penggede yang menginginkan terjaganya trah atau "darah murni” saja.

Menyandingkan makam adipati dengan makam sahabat yang merupakan keturunan Tionghoa adalah hal yang istimewa karena etnis Tionghoa dikenal seringkali berselisih paham dengan etnis lokal, terutama karena kemampuan berdagang mereka yang seringkali dianggap menjadi suatu ancaman bagi warga lokal (Priyadi, 2013).

Ada suatu pelajaran berharga yang hendak disampaikan bahwa perbedaan suku, ras, agama, dan antar golongan (SARA) bukanlah hal yang patut untuk dirisaukan atau dianggap dapat mengganggu kehidupan. Hal ini sekaligus mengisyaratkan dan menjadi simbol kerukunan antar umat beragama dan antar suku. Bahwa suku dan agama lain adalah suatu realitas tak terhindarkan dan sebuah kenyataan yang harus dihadapi, tanpa perlu disikapi berlebihan yang justru dapat mendatangkan konflik dan perpecahan. Perbedaan bukanlah sesuatu yang pantas untuk diperdebatkan.

\section{SIMPULAN}

Babad Banyumas memberikan pembelajaran mengenai nilai-nilai kearifan yang memiliki peran sebagai pedoman dalam kehidupan bermasayarakat. Dari cerita dan peristiwa yang 
disajikan dalam Babad Banyumas Wirjaatmadja dapat disarikan nilai-nilai positif yang coba untuk diwariskan dari leluhur orang Banyumas kepada generasi penerus.

Nilai-nilai kearifan yang diperoleh antara lain ajaran berterima kasih, nilai religius, nilai tolong-menolong, nilai persatuan, nilai musyawarah untuk mufakat, nilai keadilan dan kesejahteraan umum, nilai cinta damai dan anti kekerasan, serta nilai kekeluargaan dan kerukunan. Dalam perkembangannya tradisi-tradisi sebagaimana yang ditampilkan dalam Babad Banyumas mengalami kelenturan budaya yang berkembang sesuai dengan dinamika masyarakat.

Ajaran nilai positif yang dihadirkan dalam Babad Banyumas merupakan idealisme yang dicontohkan dengan menghadirkan harmoni antara manusa (jagad cilik) dengan semesta (jagad gedhe )sekaligus menunjukan bahwa manusia juga wajib menjaga harmoni dengan alam, Tuhan, dan terlebih kepada sesama manusia. Nilai-nilai kearifan dalam Babad Banyumasmerupakan kekayaan leluhur yang hingga kini masih relevan untuk dijadikan sebagai dasar acuan dalam pola relasi kemasyarakatan bahkan menjadi modal sosial yang penting bagi memperkuat persatuan dan kesatuan bangsa.

\section{DAFTAR PUSTAKA}

Adisarwono. (1985). Riwayat Banyumas. Sala: Tiga Serangkai.

Herusatoto, B. (2008). Banyumas Sejarah Budaya, Bahasa, Watak. Yogyakarta: LkiS.

Kastolani, \& Yusof, A. (2016). Relasi Islam Dan Budaya Lokal. Kontemplasi, 04(01), 66.

Khoeriyah, N. (2017). Penguatan Karakter Melalui Nilai-Nilai Kearifan Lokal dalam Babad Banyumas. Sejarah Lokal: Tantangan Dan Masa Depan, 83-91. Malang: Universitas Negeri Malang.

Kusumah, S. D. (2013). Kajian Kampung-kampung Adat Sebagai Penyangga Tradisi dan Kearifan Lokal di Jawa Barat. In Kearifan Lokal dan Lingkungan (pp. 47-60). Jakarta: PT.Gading Inti Prima dan Pusat Penelitian dan Pengembangan Kebudayaan, Kementrian Pendidikan dan Kebudayaan RI.

Maulidina, B. H., Wardani, N. E., \& Suryanto, E. (2017). Kritik Sosial dan Pendidikan Karakter Dalam Novel Babad Ngalor Ngidul Karya Elizabeth D. Inandiak. Basastra Jurnal Penelitian Bahasa, Sastra Indonesia Dan Pengajarannya, 5(1), 30-45.

Nasucha, Y. (2000). Sadranan: Adat Budaya Masyarakat Jawa. Icdetah Journal, 1(20), 220.

Priyadi, S. (2006). Babad Banyumas dan Versi-Versinya. Bahasa Dan Seni, 1(Februari), 75-103. 
Priyadi, S. (2013). Sejarah Mentalitas Banyumas. Yogyakarta: Ombak.

Priyadi, S. (2019). Babad Banyumas Versi Wirjaatmadjan dan Teks-Teks Transformasinya. JSSH (Jurnal Sains Sosial Dan Humaniora), 2(2), 237. https://doi.org/10.30595/jssh.v2i2.3031

Putra, A. M., Bahtiar, \& Upe, A. (2018). Eksistensi Kebudayaan Tolong Menolong (Kaseise) Sebagai Bentuk Solidaritas Sosial Pada Masyarakat Muna (Studi di Desa Mataindaha Kecamatan Pasikolaga). Neo Societal, 3(2), 1-8.

Rockhyatmo, A. (2018). Nilai Kearifan Di Dalam Babad Tanah Jawi. Jentera, 7(2), 182-197.

Satibi, E. T. (2015). Babad Panjalu (Kajian Struktural, Semiotik, dan Etnopedagogik). Lokabasa, 6(1), 53-64. https://doi.org/10.17509/jlb.v6i1.3168

Suwarno, S., Saddhono, K., \& Wardani, N. E. (2018). Sejarah, Unsur Kebudayaan, Dan Nilai Pendidikan Karakter Dalam Legenda Sungai Naga. RETORIKA: Jurnal Bahasa, Sastra, Dan Pengajarannya, 11(2), 194. https://doi.org/10.26858/retorika.v11i2.5972

Teeuw, A. (1984). Sastra dan Ilmu Sastra: Pengantar Teori Sastra. Jakarta: Pustaka Jaya.

Widianti, N., Nuryatin, A., \& Indiatmoko, B. (2017). Nilai Moral Dalam Cerita Babad Cirebon: Berdasarkan Penceritaan Di Keraton Kanoman. Indonesian Language Education and Literature, 3(1), 24. https://doi.org/10.24235/ileal.v3i1.1571

Widyaningsih, R. (2014). Bahasa Ngapak dan Mentalitas Orang Banyumas: Tinjauan dari Perspektif Filsafat Bahasa Hans-Georg Gadamer. Jurnal Ultiama Humaniora, II(2), 186-200.

Wirjaatmadja, R. A. (1898). Babad Banjoemas. Purwokerto: Electrische Drukkerij TAN Poerbolinggo.

Yunus, A., Ks, S. D., Mintosih, S., Soeloso, \& Soimun. (1995). Kesenian Dalang Jemblung Sebagai Sarana Penyebaran Nilai Budaya. Jakarta: Departemen Pendidikan dan Kebudayaan Direktorat Sejarah dan Nilai Tradisional. 